\title{
Physician-Patient Language Discordance and Poor Health Outcomes: A Systematic Scoping Review
}

\author{
Naomi Cano-Ibáñez ${ }^{1,2,3}$, Yasmin Zolfaghari ${ }^{4}$, Carmen Amezcua-Prieto ${ }^{1,2,3 *}$ and \\ Khalid Saeed Khan ${ }^{1,2}$ \\ ${ }^{1}$ Department of Preventive Medicine and Public Health, Faculty of Medicine, University of Granada, Granada, Spain, \\ ${ }^{2}$ Consortium for Biomedical Research in Epidemiology and Public Health (CIBERESP), Granada, Spain, ${ }^{3}$ Instituto de \\ Investigación Biosanitaria ibs. GRANADA, Granada, Spain, ${ }^{4}$ Women's Health Research Unit, Barts and the London School of \\ Medicine and Dentistry, London, United Kingdom
}

OPEN ACCESS

Edited by:

Akshaya Neil Arya,

McMaster University, Canada

Reviewed by:

Catherine Tong,

University of Waterloo, Canada Jenny Flagler-George,

University of Waterloo, Canada

*Correspondence:

Carmen Amezcua-Prieto carmezcua@ugr.es

Specialty section:

This article was submitted to Family Medicine and Primary Care,

a section of the journal

Frontiers in Public Health

Received: 25 November 2020

Accepted: 08 February 2021

Published: 19 March 2021

Citation:

Cano-Ibáñez N, Zolfaghari Y,

Amezcua-Prieto $C$ and Khan KS (2021) Physician-Patient Language

Discordance and Poor Health

Outcomes: A Systematic Scoping

Review.

Front. Public Health 9:629041. doi: 10.3389/fpubh.2021.629041
Objective: This systematic review assessed whether physician-patient language concordance, compared with discordance, is associated with better health outcomes.

Methods: A systematic literature search was conducted, without language restrictions, using PubMed, EMBASE, Web of Science, and PsycINFO, from inception to July 2020. We included studies that evaluated the effects of physician-patient language concordance on health outcomes. Articles were screened, selected, and data-extracted in duplicate. Review protocol was prospectively registered (PROSPERO, CRD42020157229).

Results: There were 541 citations identified through databases and eight citations through reverse search and Google Scholar. A total of 15 articles (84,750 participants) were included reporting outcomes within five domains: diabetes care (four studies), inpatient care (five studies), cancer screening (three studies), healthcare counseling (two studies), and mental health care (one study). Ten studies were of good quality, four were fair, and one was poor, according to the modified Newcastle-Ottawa Scale. Eight studies (53\%) showed a significant negative association between language discordance and at least one clinical outcome. Five studies (33\%) found no association.

Conclusion: Over half the evidence collated showed that physician-patient language concordance was associated with better health clinical outcomes.

Keywords: language concordance, physician, patient, health outcomes, migrants

\section{INTRODUCTION}

In the last decade, around $3.4 \%$ of the world population ( 258 million) has migrated, the majority into the United States (USA) (1). In 2018, 21.8 million of 446.8 million people in the European Union (EU) were non-EU immigrants, equating to $\sim 4.9 \%$ of the total population across all 27 countries (2). With an ever-growing number of migrants, a subset of whom include asylum seekers and refugees who face specific healthcare challenges, many also face linguistic obstacles in accessing adequate healthcare services (3). 
Language differences between healthcare providers and migrant patients, in addition to restrictive legal status and socioeconomic difficulties, are recognized as a major global healthcare barrier (4). However, the evidence of the negative effect of language discordance on healthcare provision is not completely understood. Language differences have been associated with medication non-compliance, adverse drug events, and underuse of preventative care $(5,6)$. Interpreters may play a role in addressing language discordance (7), but this intervention is associated with shortcomings including longer waiting times, increased consultation duration, and an increased financial burden on healthcare services (8). Insurance in private healthcare systems may not cover interpreter costs, and, surprisingly, only around half of EU member states provide free interpreting services (9). Thus, alternative approaches in tackling language barriers are sought on a daily basis in health services, to varying effects.

Current literature exploring associations between language barriers and health outcomes, e.g., patient safety, provide an incomplete understanding of the health disparities observed (10). When compared with language discordance in individual studies, physician-patient language concordance has been associated with increased patient follow-up among those affected by chronic illness, avoidance of medication complications, and reduction in the use of emergency care services (11). Previous reviews have reported a positive impact of language concordance on subjective outcomes, such as care satisfaction, access to healthcare, and perceived quality of care. In such cases, it is possible that the positive effects of language concordance have been magnified due to the lack of objectivity. Reviews with laboratory-based health measures have been limited to evaluations of diabetic patients (12). Furthermore, previous reviews appear not to have followed PRISMA reporting guidelines (13). Evaluations using AMSTAR tool (14) have found them to be of poor methodological quality, without an independent prospective registry $(11,12)$ or an assessment of risk of bias in the studies included (11). To build upon previous findings, to explore the effects across a wider range of healthcare domains, and to focus attention on objective clinical outcomes, we undertook a robust systematic review to comprehensively assess whether physician-patient language concordance, compared to discordance, is associated with improvements in health outcomes.

\section{METHODS}

The protocol of the systematic review was prospectively registered in PROSPERO with the registration number CRD42020157229 (https://www.crd.york.ac.uk/PROSPERO). We followed PRISMA reporting guidelines (13). The review question (PICOS), registered in PROSPERO, was as follows: population (P): patients seeking health care; exposure (I): patient-health care provider language discordance; comparison (C): patient-health care provider language concordance; outcome (O): health measurements; and study design (S): systematic review of observational studies.

\section{Search Strategy and Study Selection}

A literature search was carried out in June 2020 across four bibliographic databases: PubMed, PsycINFO, Web of Science, and EMBASE. We did not apply limits to publication date or article language. In order to achieve an optimal search strategy, the following indexing terms, word variants, and free text terms were applied. The MeSH-terms combined in the search strategy were as follows: ("Language discordance" OR "Language concordance" OR "language prof*" OR “interprofessional) AND "language" ("health outcomes" OR "clinical outcomes" "diabet*" OR "hyperten*” OR “cardiovasc*” OR "psych*” OR "mental health" OR "physical health") AND (“doctor" OR "physician" OR "clinician") AND ("patient"). A manual search was also conducted, through reverse search and Google Scholar. We used EndNote bibliographic citation program to pool the articles that were yielded and remove duplicates.

Two reviewers (YZ and NC-I) independently screened the titles and abstracts and reviewed the full texts for study selection. Articles were initially screened by title and abstract and were included if they (1) were observational studies; (2) included an exposure group of patients that were identified as language concordant or discordant with their physicians; (3) identified an association between language discordance and patient health outcomes; and (4) observed health outcomes with objective health measurements, such as cancer screening rates, serum HBA1c levels, post-operative length of stay (POLS), or blood pressure measurements. Articles were excluded if they solely included self-reported measures of health outcomes or other forms of subjective outcome measures, such as patient satisfaction of care, patient experience, or medical comprehension. Articles that only included the use of interpreters and failed to explore physician-patient language concordance specifically were also excluded. Qualitative studies, reports, and gray literature were excluded.

\section{Data Extraction and Study Quality}

Two reviewers (YZ and NC-I) independently extracted data and assessed the selected study quality. The following information was obtained from the articles for analysis: first author, publication year, study locations, study design, sample size, population, type of objective health outcome(s) studied, participants' race and/or ethnicity, languages documented, effect of language concordance/discordance, comparison groups, and main findings. Risk of bias of each study was assessed using the modified Newcastle-Ottawa Scale, which addresses three aspects of quality: (1) selection: representativeness of the exposed participants to language discordant care, selection of the nonexposed participants, and ascertainment of exposure to language discordant care; (2) comparability: confounders and study design; and (3) outcome: assessment of health outcome, adequate retention of cohort (\%), and follow-up period (years) (15).

\section{Study Synthesis}

Studies were narratively categorized into five domains depending on the clinical outcome measure: diabetes care, inpatient care, cancer screening, healthcare counseling, and mental health care. We tabulated our findings. Inferences were 


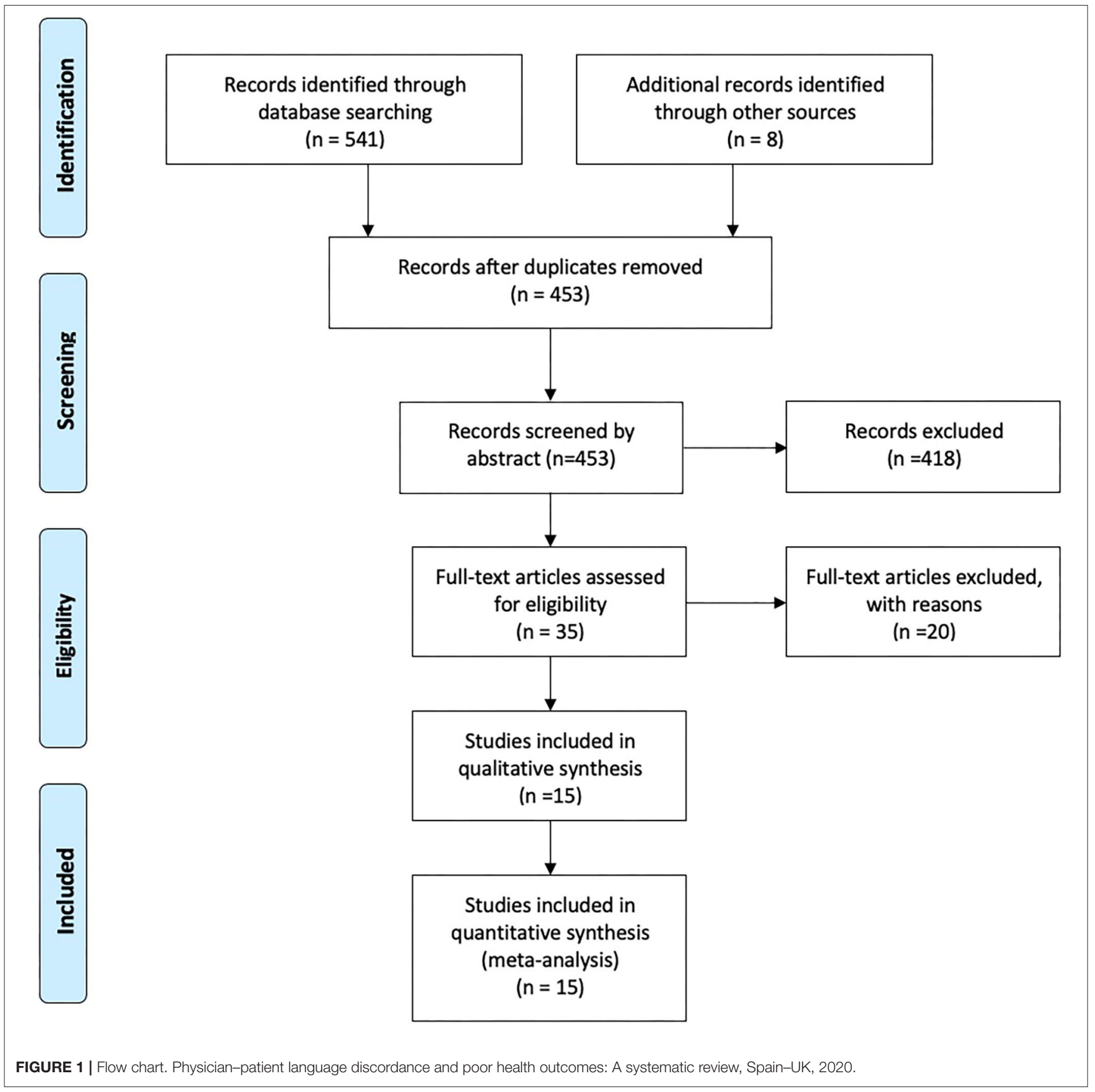

generated taking study precision and quality into account, since quantitative synthesis (meta-analysis) proved unfeasible due to substantial heterogeneity of exposure, outcome, study quality, and statistical analyses. We settled for a qualitative synthesis in the form of vote counting, which we conducted within broad exposure-outcome subgroups stratified by study quality and precision to minimize bias. Due to the wide range of health outcomes reported across studies, we summarized the direction of the results using a votecounting approach, quantifying studies on the basis of their positive, negative, or non-significant outcomes. This approach is in line with what is considered suitable $(16,17)$ to avoid subjectivity.

\section{RESULTS}

Our study search yielded 541 citations. An additional eight articles were identified through searching reference lists of relevant studies. After removal of 96 duplicates, 451 articles remained for title and abstract screening. After exclusion of 418 articles that did not meet the selection criteria, 35 studies were carried forward for full-text review and assessed for eligibility. 
Fifteen out of the 35 studies were eligible, from which data on study characteristics and main findings was extracted (Figure 1).

\section{Study Characteristics and Quality}

Out of the 15 studies, 12 studies (80\%) were conducted in the USA, one study (6.7\%) in Australia, one study (6.7\%) in Canada, and one study was based (6.7\%) in Sri Lanka. Ten studies (66.7\%) were retrospective cohort studies, four studies $(26.7 \%)$ were RCTs, and one $(6.7 \%)$ was a cross-sectional observation study. Sample size ranged from 55 to 44,983 participants. Eight out of 15 studies (53\%) focused on only Spanish-speaking patients, almost all of which had a study population of solely Hispanic patients (Table 1). Four out of 15 studies had no mention of using race/ethnicity as control variables in their study at all.

The studies addressed clinical outcomes across an array of areas in healthcare, with several studies using more than one outcome measure. Three studies focused on glycemic control in diabetic patients as an outcome measure, all of which used serum HbA1c level measurements $(20,25,31)$. Three studies measured rates of colorectal cancer screening $(19,24,30)$, two studies measured the number of emergency room visits $(18,26)$, two studies measured POLS $(26,27)$, two studies used in-hospital time to treatment $(27,33)$, and two studies used receipt of lifestyle counseling as their outcome measure $(22,23)$. Finally, one study focused on the effect of language concordance on the receipt of adequate psychiatric care (32).

All 15 studies were assessed for quality using the modified Newcastle-Ottawa Scale (Table 2). Ten studies were of good quality, four studies were of fair quality $(28,29,31,32)$, and one study was of poor quality (30), with positive, negative, or no differences in health outcomes for the language discordance compared to the language concordance group (Supplementary Figure).

\section{Assessment of Language Concordance}

The parameters of language concordance were heterogeneous across the studies, with several studies using ethnolinguistic concordance as their measure of exposure as opposed to language concordance alone. Several studies did not specify their parameters of language concordance but rather inferred it based on patients' English language proficiency and the assumption that healthcare consultations were in English. Other studies, however, had wholly inaccurate definitions of language concordance, such as Mehler et al. (31), who used patients' ethnicity and immigrant status as a proxy for limited English proficiency (LEP). Similarly, Biswas et al. (21) defined LEP patients as any participant who did not self-report English as their primary language, negating the existence of multilingual participants. The majority of studies used self-reported surveys and questionnaires to collect data on preferred language and language fluency among patients and physicians, while other studies used electronic medical databases to access patients' primary language(s).

The main findings from each study are summarized in Table 3. Compared to concordance, eight studies (53\%) showed a significant negative association between language discordance and at least one measure of clinical outcome among study participants $(20,22,23,25,27,31-33)$. Five studies (33\%) found no significant association between language discordance and the main clinical outcome $(18,19,26,28,29)$. Two studies (13\%) found a positive association between language discordance and clinical outcomes $(24,30)$. All three studies that examined diabetes showed statistically significant improvement in glycemic control $\left(\mathrm{HbA}_{1 \mathrm{c}}<8 \%\right)$ in the language-concordant groups compared to their language discordant counterparts $(20,25$, 31). Two studies also included LDL control as an additional outcome measure for diabetes care $(20,31)$, both of which also noted significant improvement following language concordance as an intervention. Four studies examined the effects of language discordance and different measures of in-hospital treatment, inclusive of POLS, 30-day mortality, and time to treatment. Three studies showed no association between language concordance and rates of mortality $(18,26,33)$.

Three studies examined the effects of language concordance and cancer screening $(19,24,30)$. Surprisingly, two out of the three studies found that language concordance actually lead to lower rates of colorectal screening (24). No significant association was found between language concordance and rates of cervical cancer and breast cancer screening (24, 30). Two aspects of healthcare counseling were assessed across two studies: lifestyle counseling (23) and post-partum contraception counseling (22). Language concordance was found to have significant association on the receipt of lifestyle counseling for diet and exercise. However, there was no association between language concordance and receipt of post-partum IUD counseling (22); however, the study noted significant effect from ethnic concordance.

One study focused on the effects of language concordance on the rates of adequate psychiatric care (eight or more psychotherapy visits), in addition to psychiatric-related ER use among participants. Language concordance results in higher rates of adequate psychiatric care in Portuguese-speaking patients (32). However, no association was found between language concordance and ER use (18).

\section{DISCUSSION}

Over half the evidence collated showed that physicianpatient language concordance was associated with better health outcomes. Although this review points to the positive effects of language concordance on objective health outcomes in specialisms such as asthma management, mental health, and glycemic control (HBA1c), based on our findings, we deduce that caution is needed in interpretation of findings. The effect of language concordance in improving health outcomes merits consideration.

Using comprehensive searches to capture all published literature and employing robust quality assessments to limit bias, our review provided positive, negative, or no associations regarding physician-patient language discordance and clinical outcomes. This is an important topic, as the proportion of migrant population in the world and in European countries is expected to rise in the next few years. This systematic review included 15 individual studies with a large sample size overall 
TABLE 1 | Study characteristics.

\begin{tabular}{|c|c|c|c|c|c|c|c|c|}
\hline References & Location & Study design & Sample size & Language (s) & Patients & Race/ethnicity & Intervention & Health outcomes \\
\hline Manson (18) & USA & $\begin{array}{l}\text { Retrospective cohort } \\
\text { study }\end{array}$ & 96 & Spanish; English & $\begin{array}{l}\text { Adult Spanish-speaking } \\
\text { population with asthma, } \\
\text { seen from July } 1979 \text { to } \\
\text { March } 1987\end{array}$ & Hispanic & $\begin{array}{l}\text { Physician-patient LC } \\
\text { vs. LD }\end{array}$ & $\begin{array}{l}\text { Serum levels of theophylline; } \\
\text { ER visits for asthma, } \\
\text { follow-up appointments }\end{array}$ \\
\hline Linsky et al. (19) & USA & $\begin{array}{l}\text { Retrospective cohort } \\
\text { study }\end{array}$ & 23,297 & $\begin{array}{l}\text { English; Spanish; } \\
\text { Other }\end{array}$ & $\begin{array}{l}\text { US civilians aged } 50 \text { or } \\
\text { more with no self-reported } \\
\text { history of colorectal cancer }\end{array}$ & $\begin{array}{l}\text { White non-Hispanic; } \\
\text { Black; Hispanic; Asian }\end{array}$ & $\begin{array}{l}\text { Physician-patient LC } \\
\text { vs. LD }\end{array}$ & $\begin{array}{l}\text { Colorectal cancer screening } \\
\text { by Fecal Occult Blood Test } \\
\text { (FOBT) and endoscopy }\end{array}$ \\
\hline Parker et al. (20) & USA & $\begin{array}{l}\text { Randomized Control } \\
\text { Trial }\end{array}$ & 1,605 & Spanish; English & $\begin{array}{l}\text { Limited English Proficiency } \\
\text { Latino patients with } \\
\text { diabetes }\end{array}$ & Hispanic & $\begin{array}{l}\text { Primary care } \\
\text { physician's LD vs. LC }\end{array}$ & $\begin{array}{l}(\mathrm{HbA} 1 \mathrm{c})<8 \% ; \mathrm{LDL}<100 \\
\mathrm{mg} / \mathrm{dL} ; \mathrm{SBP}<140 \mathrm{~mm} \mathrm{Hg})\end{array}$ \\
\hline Biswas et al. (21) & Australia & $\begin{array}{l}\text { Retrospective cohort } \\
\text { study }\end{array}$ & 650 & Vietnamese; Greek & $\begin{array}{l}\text { Patients undergoing primary } \\
\text { PCl between } 2013 \text { and } \\
2016\end{array}$ & Not reported & $\begin{array}{l}\text { LEP vs. EP patients } \\
\text { with English speaking } \\
\text { physicians }\end{array}$ & Total ischaemic time \\
\hline Karra et al. (22) & Sri Lanka & Cluster randomized trial & 4,497 & Sinhala; Tamil & $\begin{array}{l}\text { Women who delivered at six } \\
\text { hospitals in Sri Lanka } \\
\text { between } 2015 \text { and } 2017\end{array}$ & $\begin{array}{l}\text { Sinhalese; } \\
\text { Non-Sinhalese }\end{array}$ & $\begin{array}{l}\text { Ethnolinguistic } \\
\text { concordance vs. } \\
\text { Ethnolinguistic } \\
\text { discordance }\end{array}$ & $\begin{array}{l}\text { Rates of post-partum } \\
\text { counseling }\end{array}$ \\
\hline $\begin{array}{l}\text { Eamranond et al. } \\
\text { (23) }\end{array}$ & USA & $\begin{array}{l}\text { Retrospective cohort } \\
\text { study }\end{array}$ & 306 & Spanish & $\begin{array}{l}\text { Spanish-speaking patients } \\
\text { with interpreter services } \\
\text { between } 2001 \text { and } 2006\end{array}$ & Not recorded & $\begin{array}{l}\text { Patients with LD vs. LC } \\
\text { physicians }\end{array}$ & $\begin{array}{l}\text { Counseling on exercise, } \\
\text { diet, and smoking. }\end{array}$ \\
\hline $\begin{array}{l}\text { Eamranond et al. } \\
\text { (24) }\end{array}$ & USA & $\begin{array}{l}\text { Retrospective cohort } \\
\text { study }\end{array}$ & 306 & Spanish & $\begin{array}{l}\text { Spanish-speaking patients } \\
\text { with interpreter services } \\
\text { between } 2001 \text { and } 2006\end{array}$ & Not recorded & $\begin{array}{l}\text { Patients with LD vs. LC } \\
\text { physicians }\end{array}$ & $\begin{array}{l}\text { Hyperlipidaemia; Cervical } \\
\text { cancer; Breast cancer and } \\
\text { colorectal screening }\end{array}$ \\
\hline $\begin{array}{l}\text { Fernandez et al. } \\
\text { (25) }\end{array}$ & USA & Cross-sectional study & 6,738 & Spanish; English & $\begin{array}{l}\text { Limited English Proficiency } \\
\text { Latinos with diabetes }\end{array}$ & Hispanic; White & $\begin{array}{l}\text { LEP patients with LD } \\
\text { physician vs. LEP } \\
\text { patients with LC } \\
\text { physicians }\end{array}$ & $\begin{array}{l}\text { Poor glycemic control } \\
(\mathrm{HbA1C}>9 \%)\end{array}$ \\
\hline Inagaki et al. (26) & USA & $\begin{array}{l}\text { Retrospective cohort } \\
\text { study }\end{array}$ & 324 & $\begin{array}{l}\text { Albanian; Bosnian; } \\
\text { Haitian Creole; Italian; } \\
\text { Portuguese; Spanish }\end{array}$ & $\begin{array}{l}\text { Non-English-speaking } \\
\text { patients who underwent } \\
\text { inguinal bypass for } \\
\text { claudication at an urban, } \\
\text { academic medical center, } \\
\text { between } 2007 \text { and } 2014\end{array}$ & $\begin{array}{l}\text { American Indian/Alaska } \\
\text { Native; Black or African } \\
\text { American; White; } \\
\text { Hispanic or Latino }\end{array}$ & $\begin{array}{l}\text { English speaking } \\
\text { patient group vs. } \\
\text { Non-English-speaking } \\
\text { patient group }\end{array}$ & $\begin{array}{l}\text { POLS, 30-day wound } \\
\text { infections, 30-day adverse } \\
\text { graft events, unplanned } \\
\text { readmissions } \leq 30 \text { days, } \\
\text { and return visits } \leq 30 \text { days }\end{array}$ \\
\hline $\begin{array}{l}\text { John-Baptiste et } \\
\text { al. (27) }\end{array}$ & Canada & $\begin{array}{l}\text { Retrospective cohort } \\
\text { study }\end{array}$ & 44,983 & $\begin{array}{l}\text { English; Portuguese } \\
\text { Italian; Chinese, } \\
\text { Greek; Polish; } \\
\text { Spanish; others }\end{array}$ & $\begin{array}{l}\text { Limited English Proficient } \\
\text { inpatients at three hospitals } \\
\text { between } 1993 \text { and } 1999\end{array}$ & Not recorded & $\begin{array}{l}\text { LEP vs. English } \\
\text { Proficient patients }\end{array}$ & $\begin{array}{l}\text { POLS and odds of } \\
\text { in-hospital death }\end{array}$ \\
\hline Rostanki et al. (28) & USA & $\begin{array}{l}\text { Retrospective cohort } \\
\text { study }\end{array}$ & 279 & $\begin{array}{l}\text { English; Spanish; } \\
\text { Other }\end{array}$ & $\begin{array}{l}\text { Patients who received tissue } \\
\text { plasminogen activator in } \\
\text { emergency department } \\
\text { between } 2011 \text { and } 2014\end{array}$ & $\begin{array}{l}\text { Hispanic/Latino } \\
\text { White }\end{array}$ & LC vs. LD patients & $\begin{array}{l}\text { Door to Imaging time (DIT), } \\
\text { Imaging to Needle (ITN) } \\
\text { Time in thrombolysis } \\
\text { pathway }\end{array}$ \\
\hline
\end{tabular}




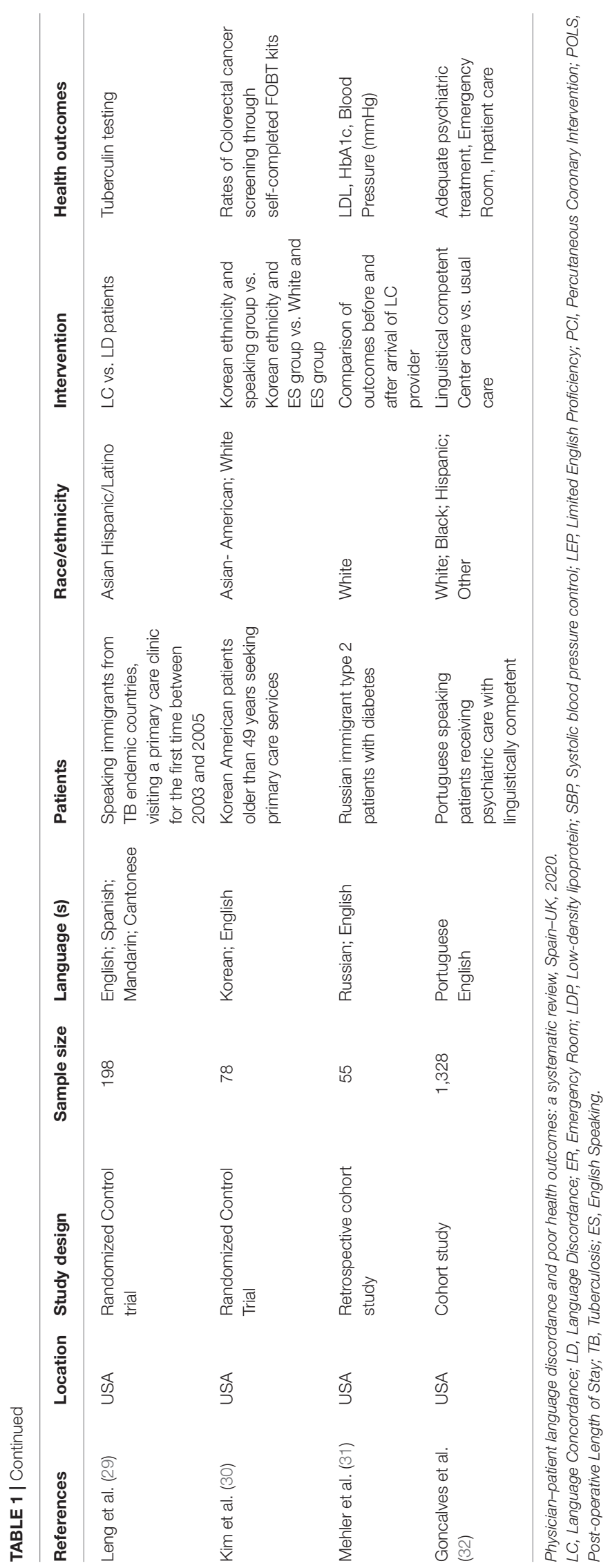

and with mostly good quality evidence. Thus, our review meets the criteria for a high-quality evidence synthesis.

There were several limitations to this review also. Firstly, because most studies are from the USA, we cannot generalize findings to other contexts. USA was overrepresented, being the study location of 12/15 studies. None of the studies were conducted in Europe, which faces the most rapidly increasing influx of migrants in need of language concordant care. Furthermore, only one study (22) was conducted in a nonWestern setting, and thus, we were unable to assess any crosscultural differences in the effects of language concordance. There was little variation in the languages studied, with most studies focusing on Spanish-speaking and English-speaking patients. These features may affect the generalizability of our findings, despite the fact that English and Spanish are the most widely spoken languages worldwide (34). Half of the studies included in this review were made up of only Hispanic patients. According to the 2018 United States Census Bureau, Hispanic people in the United States are $18.3 \%$ of total population. Many of them are undocumented, lack health care coverage, and face many stereotypes, as well as disadvantages that would also affect their health, access to health, and behavior of medical care toward them.

Although most studies included were of good quality, there was heterogeneity in the definitions of language concordance across the studies, making it difficult to ascertain its effects. Also, self-reported data in the studies may affect the validity of the methodology, as it may lead to physicians inaccurately reporting their own fluency. Additionally, using electronic patient records to collect data on language and patients' race/ethnicity means relying on the accuracy of previous documentation from healthcare administrative staff, which may result in information bias. We did not examine the effects of sex and gender in our results, which may affect sex-specific outcomes such as rates of cervical cancer screening and contraceptive counseling (35). Finally, 2/15 studies included were conducted by the same author $(23,24)$ and used the same sample of patients, leading to the potential for bias with regard to the outcomes of the subsequent study.

\section{Implications}

Two of our studies found that language concordance negatively impacted the rates of colorectal cancer screening, both of which focused on Spanish-speaking populations $(19,24)$. This finding may have resulted from the presence of higher rates of informed consent among language-concordant groups who may not have fully understood the process of colorectal cancer screening, which can involve invasive procedures such as colonoscopies or endoscopies, without the intervention of language concordant care. Contrastingly, the study by Kim et al. (30), which focused on a Korean-American population, demonstrated an increased uptake of colorectal cancer screening in the language-concordant group, perhaps pointing to the covert influences of ethnicity in rates of colorectal cancer screening. Previous studies have highlighted a pattern of reduced rates of colorectal cancer screening among Latinos, comparative to the general population. Indeed, several studies suggest that educational interventions 
TABLE 2 | Quality assessment (modified Newcastle-Ottawa Assessment Scale).

\begin{tabular}{|c|c|c|c|c|c|c|c|c|c|}
\hline \multirow[b]{2}{*}{ References } & \multicolumn{4}{|c|}{ Selection } & \multirow{2}{*}{$\begin{array}{l}\text { Comparability } \\
\text { Comparability of } \\
\text { cohorts }\end{array}$} & \multicolumn{3}{|c|}{ Outcomes } & \multirow[t]{2}{*}{ Quality score } \\
\hline & $\begin{array}{l}\text { Representativeness } \\
\text { of exposed cohort }\end{array}$ & $\begin{array}{l}\text { Selection of } \\
\text { non-exposed } \\
\text { cohort }\end{array}$ & $\begin{array}{l}\text { Ascertainment of } \\
\text { exposure }\end{array}$ & $\begin{array}{l}\text { Outcome not at } \\
\text { start of study }\end{array}$ & & $\begin{array}{l}\text { Assessment of } \\
\text { outcome }\end{array}$ & $\begin{array}{l}\text { Length of } \\
\text { follow up }\end{array}$ & $\begin{array}{l}\text { Adequacy of } \\
\text { follow up }\end{array}$ & \\
\hline Manson (18) & $\begin{array}{l}\text { Not truly } \\
\text { representative of } \\
\text { asthmatic patients and } \\
\text { the sample size was } \\
\text { small }\end{array}$ & Yes $^{*}$ & $\begin{array}{l}\text { Patient language status } \\
\text { from chart notes or } \\
\text { estated by their } \\
\text { physicians }\end{array}$ & Yes $^{*}$ & $\begin{array}{l}\text { Adjusted by Age, } \\
\text { gender, pay-status, } \\
\text { disease severity**}\end{array}$ & $\begin{array}{l}\text { Electronic medical } \\
\text { record }^{*}\end{array}$ & Yes $^{*}$ & $>40 \% *$ & Good \\
\hline Linsky et al. (19) & $\begin{array}{l}\text { Representative of } \\
\text { non-English speaking } \\
\text { patients that visit } \\
\text { primary care services* }\end{array}$ & Yes $^{*}$ & $\begin{array}{l}\text { Language from Survey } \\
\text { and Self-administered } \\
\text { Questionnaire* }\end{array}$ & Yes $^{*}$ & $\begin{array}{l}\text { Race/ethnicity, age, } \\
\text { education, marital } \\
\text { status, family income, } \\
\text { employment }{ }^{\star \star}\end{array}$ & $\begin{array}{l}\text { Self-reported rates of } \\
\text { FOBT and endoscopy }\end{array}$ & Yes $^{*}$ & No loss of data* & Good \\
\hline Parker et al. (20) & $\begin{array}{l}\text { Representative of LEP } \\
\text { Latinos with type } 2 \\
\text { diabetes }^{*}\end{array}$ & Yes $^{*}$ & $\begin{array}{l}\text { Spanish speaking } \\
\text { physicians if they } \\
\text { self-reported "high" } \\
\text { fluency in Spanish or } \\
\text { without the aid of } \\
\text { interpreters* }\end{array}$ & Yes $^{*}$ & $\begin{array}{l}\text { Age, sex, economic } \\
\text { race/ethnicity**}\end{array}$ & $\begin{array}{l}\text { Electronic medical } \\
\text { record }^{*}\end{array}$ & *Yes & No loss of data* & Good \\
\hline Biswas et al. (21) & $\begin{array}{l}\text { Representative of } \\
\text { patients undergoing } \\
\text { Percutaneous } \\
\text { Coronary Intervention } \\
\text { in Melbourne, } \\
\text { Australia* }\end{array}$ & Yes $^{\star}$ & $\begin{array}{l}\text { Language other than } \\
\text { English as their primary } \\
\text { language were defined } \\
\text { as having LEP }\end{array}$ & Yes $^{*}$ & $\begin{array}{l}\text { Adjusted by age, sex, } \\
\text { BMI, Comorbidities } \\
\text { hospital long stay, } \\
\text { mortality }{ }^{\star \star}\end{array}$ & $\begin{array}{l}\text { Total ischaemic time of } \\
\text { participants was } \\
\text { accessed through an } \\
\text { electronic database* }\end{array}$ & Yes $^{*}$ & No loss of data* & Good \\
\hline Karra et al. (22) & $\begin{array}{l}\text { Representative of } \\
\text { post-partum women } \\
\text { in Sri Lanka as data } \\
\text { was collected from } 6 \\
\text { major hospitals* }\end{array}$ & Yes $^{*}$ & $\begin{array}{l}\text { Questionnaires } \\
\text { distributed to women } \\
\text { by investigators }\end{array}$ & Yes $^{*}$ & $\begin{array}{l}\text { Adjusted by number of } \\
\text { live births, woman's } \\
\text { maternal education and } \\
\text { work }^{\star \star}\end{array}$ & $\begin{array}{l}\text { Self-reports of receipt } \\
\text { of Post-partum } \\
\text { counseling }\end{array}$ & Yes $^{\star}$ & $\begin{array}{l}62 \% \text { of women } \\
\text { follow up* }\end{array}$ & Good \\
\hline $\begin{array}{l}\text { Eamranond et al. } \\
\text { (23) }\end{array}$ & $\begin{array}{l}\text { Representative of } \\
\text { Latino adult patients } \\
\text { as the sample was } \\
\text { selected from a two } \\
\text { large primary care } \\
\text { facilities }{ }^{\star}\end{array}$ & Yes $^{*}$ & $\begin{array}{l}\text { Data was accessed } \\
\text { through an electronic } \\
\text { medical record* }\end{array}$ & Yes $^{*}$ & $\begin{array}{l}\text { Adjusted by age, sex, } \\
\text { number of visits }{ }^{\star *}\end{array}$ & $\begin{array}{l}\text { Electronically } \\
\text { documented lifestyle } \\
\text { counseling * }\end{array}$ & Yes $^{\star}$ & No loss of data* & Good \\
\hline $\begin{array}{l}\text { Eamranond et al. } \\
\text { (24) }\end{array}$ & $\begin{array}{l}\text { Representative of } \\
\text { Latino adult patients } \\
\text { as the sample was } \\
\text { selected from a two } \\
\text { large primary care } \\
\text { facilities* }\end{array}$ & Yes $^{*}$ & $\begin{array}{l}\text { Data was accessed } \\
\text { through an electronic } \\
\text { medical record }\end{array}$ & Yes $^{*}$ & $\begin{array}{l}\text { Adjusted by age, sex, } \\
\text { number of primary care } \\
\text { visits }{ }^{\star \star}\end{array}$ & $\begin{array}{l}\text { Records of screening } \\
\text { for hyperlipidaemia, } \\
\text { diabetes, cervical, } \\
\text { breast and colorectal } \\
\text { cancer* }\end{array}$ & Yes $^{\star}$ & No loss of data* & Good \\
\hline $\begin{array}{l}\text { Fernandez et al. } \\
\text { (25) }\end{array}$ & $\begin{array}{l}\text { Representative of } \\
\text { Latinos with type } 2 \\
\text { diabetes as data was } \\
\text { collected from a } \\
\text { diabetes registry* }\end{array}$ & Yes $^{*}$ & $\begin{array}{l}\text { Self-completed survey } \\
\text { in } 5 \text { languages via mail, } \\
\text { web or phone }\end{array}$ & Yes $^{*}$ & $\begin{array}{l}\text { Adjusted by age, sex, } \\
\text { education, incomes, } \\
\text { years with DM, Hba1c, } \\
\text { Comorbidity ** }\end{array}$ & $\begin{array}{l}\text { Laboratory results } \\
\text { obtained during routine } \\
\text { clinical care }\end{array}$ & Yes $^{\star}$ & No loss of data* & Good \\
\hline
\end{tabular}


TABLE 2 | Continued

\begin{tabular}{|c|c|c|c|c|c|c|c|c|c|}
\hline \multirow[b]{2}{*}{ References } & \multicolumn{4}{|c|}{ Selection } & \multirow{2}{*}{$\begin{array}{l}\text { Comparability } \\
\text { Comparability of } \\
\text { cohorts }\end{array}$} & \multicolumn{3}{|c|}{ Outcomes } & \multirow[t]{2}{*}{ Quality score } \\
\hline & $\begin{array}{l}\text { Representativeness } \\
\text { of exposed cohort }\end{array}$ & $\begin{array}{l}\text { Selection of } \\
\text { non-exposed } \\
\text { cohort }\end{array}$ & $\begin{array}{l}\text { Ascertainment of } \\
\text { exposure }\end{array}$ & $\begin{array}{l}\text { Outcome not at } \\
\text { start of study }\end{array}$ & & $\begin{array}{l}\text { Assessment of } \\
\text { outcome }\end{array}$ & $\begin{array}{l}\text { Length of } \\
\text { follow up }\end{array}$ & $\begin{array}{l}\text { Adequacy of } \\
\text { follow up }\end{array}$ & \\
\hline Inagaki et al. (26) & $\begin{array}{l}\text { Representative of } \\
\text { patients who have } \\
\text { undergone inguinal } \\
\text { bypass, collected from } \\
\text { a large medical center } \\
\text { over a } 7 \text {-year period* }\end{array}$ & Yes $^{*}$ & $\begin{array}{l}\text { LC was collected using } \\
\text { electronic medical } \\
\text { records* }\end{array}$ & Yes $^{*}$ & $\begin{array}{l}\text { Age, gender, race, } \\
\text { ethnicity, BMI, medical } \\
\text { comorbidities smoking } \\
\text { status and insurance } \\
\text { status ** }\end{array}$ & $\begin{array}{l}\text { Participants identified } \\
\text { via the electronic } \\
\text { medical records using } \\
\text { relevant terminology } \\
\text { codes* }^{*}\end{array}$ & Yes $^{*}$ & No loss of data* & Good \\
\hline $\begin{array}{l}\text { John-Baptiste et } \\
\text { al. (27) }\end{array}$ & $\begin{array}{l}\text { Representative of } \\
\text { Canadian inpatients, } \\
\text { sample was collected } \\
\text { across } 3 \text { large } \\
\text { Canadian hospitals } \\
\text { over a 6-year period }\end{array}$ & Yes $^{\star}$ & $\begin{array}{l}\text { LC collected from an } \\
\text { electronic patient } \\
\text { information system }{ }^{*}\end{array}$ & Yes $^{*}$ & $\begin{array}{l}\text { Age, sex, marital } \\
\text { status, comorbid } \\
\text { diagnosis codes, } \\
\text { language and Charlson } \\
\text { score }^{\star *}\end{array}$ & $\begin{array}{l}\text { Canadian Institute for } \\
\text { Health Information } \\
\text { discharge abstract } \\
\text { database* }^{*}\end{array}$ & Yes* $^{*}$ & No loss of data* & Good \\
\hline Rostanki et al. (28) & $\begin{array}{l}\text { No representative of } \\
\text { patients receiving } \\
\text { thrombolysis } \\
\text { treatment post-stroke }\end{array}$ & Yes $^{\star}$ & $\begin{array}{l}\text { Primary language } \\
\text { determined by } \\
\text { self-report, via } \\
\text { questionnaire }\end{array}$ & Yes $^{*}$ & Yes $^{\star \star}$ & $\begin{array}{l}\text { The electronic medical } \\
\text { record was reviewed } \\
\text { for all patients with } \\
\text { treatment }{ }^{\star}\end{array}$ & Yes $^{*}$ & No loss of data* & Fair \\
\hline Leng et al. (29) & $\begin{array}{l}\text { Participants are not } \\
\text { representative of } \\
\text { Latino and Asian } \\
\text { immigrants }\end{array}$ & Yes $^{\star}$ & $\begin{array}{l}\text { All participants } \\
\text { completed a } \\
\text { demographic } \\
\text { questionnaire }\end{array}$ & Yes* $^{*}$ & $\begin{array}{l}\text { Age, education, year of } \\
\text { migration, primary } \\
\text { language, or } \\
\text { self-reported health } \\
\text { status assessed }^{\star \star}\end{array}$ & $\begin{array}{l}\text { Clinical data were } \\
\text { abstracted from } \\
\text { medical records }{ }^{\star}\end{array}$ & Yes* $^{*}$ & $\begin{array}{l}\text { Only } 17 \text { of the } \\
191(8.9 \%) \\
\text { patients were } \\
\text { referred for } \\
\text { tuberculin } \\
\text { testing. }\end{array}$ & Fair \\
\hline Kim et al.(30) & $\begin{array}{l}\text { Representative of } \\
\text { Korean Americans, } \\
\text { recruited through } \\
\text { Korean } \\
\text { community-based } \\
\text { organizations * }\end{array}$ & Yes $^{\star}$ & $\begin{array}{l}\text { Bilingual pre- and } \\
\text { post-survey }\end{array}$ & Yes $^{*}$ & - & $\begin{array}{l}\text { No-cost FOBT kit at } \\
\text { the end of the session, } \\
\text { and had } 4 \text { weeks to } \\
\text { mail back the FOBT kit }\end{array}$ & - & - & Poor \\
\hline Mehler et al. (31) & $\begin{array}{l}\text { Study Participants } \\
\text { were not } \\
\text { representative of } \\
\text { Russian patients with } \\
\text { diabetes }\end{array}$ & Yes $^{*}$ & $\begin{array}{l}\text { LC was not accurately } \\
\text { in English }\end{array}$ & Yes $^{*}$ & $\begin{array}{l}\text { Non adjusted by } \\
\text { control variables. }\end{array}$ & $\begin{array}{l}\text { Hba1c and Lipid panels } \\
\text { accessed through the } \\
\text { administrative } \\
\text { database }^{*}\end{array}$ & Yes $^{*}$ & No loss of data* & Fair \\
\hline $\begin{array}{l}\text { Goncalves et al. } \\
\text { (32) }\end{array}$ & $\begin{array}{l}\text { No representative of } \\
\text { Portuguese speaking } \\
\text { psychiatric patients in } \\
\text { the USA }\end{array}$ & Yes $^{*}$ & $\begin{array}{l}\text { LC: any patient with } \\
\text { Portuguese as primary } \\
\text { language and mental } \\
\text { health visit* }\end{array}$ & - & $\begin{array}{l}\text { Age, marital status, } \\
\text { race/ethnicity sex; and } \\
\text { diagnosis of mental } \\
\text { disorder }^{\star *}\end{array}$ & Electronic database* & Yes $^{*}$ & No loss of data* & Fair \\
\hline
\end{tabular}

Physician-patient language discordance and poor health outcomes: A systematic review, Spain-UK, 2020.

LC, Language Concordance; FOBT, Fecal Occult Blood Test; LEP, Limited English Proficient; DM, Diabetes Mellitus. A "good" quality score required 3 or 4 stars in selection, 1 or 2 stars in comparability, and 2 or 3 stars in outcomes. A

"fair" quality score required 2 stars in selection, 1 or 2 stars in comparability, and 2 or 3 stars in outcomes. A "poor" quality score reflected 0 or 1 star(s) in selection, or 0 stars in comparability, or 0 or 1 star(s) in outcomes. 
TABLE 3 | Results of studies.

\begin{tabular}{|c|c|c|c|c|c|c|}
\hline $\begin{array}{l}\text { Primary author, } \\
\text { publication date, } \\
\text { location }\end{array}$ & Outcomes & Measures & $\begin{array}{l}\text { Language discordance } \\
\text { (LD) vs. language } \\
\text { concordance (LC) }\end{array}$ & $\begin{array}{l}\text { Relative risk } \\
\text { (RR)/odds ratio } \\
\text { (OR)/mean/prevalence }\end{array}$ & $\begin{array}{l}\text { 95\% Confidence intervals } \\
\text { (CI)/interquartile range } \\
\text { (IQR) }\end{array}$ & $P$-value \\
\hline \multirow[t]{4}{*}{$\begin{array}{l}\text { Manson, et al. (18), } \\
\text { United States }\end{array}$} & $\begin{array}{l}\text { Medication adherence to asthma } \\
\text { inhalers }\end{array}$ & $\begin{array}{l}\text { Non-therapeutic serum theophylline } \\
\text { levels (10-20 mg/dl) }\end{array}$ & $\mathrm{LD}=59 \% \mathrm{LC}=50 \%$ & $\mathrm{OR}=1.72$ & Cl: $0.69-4.30$ & 0.24 \\
\hline & Emergency room (ER) use & Number of ER attendance & $L D=48 \% L C=55 \%$ & $\mathrm{OR}=2.07$ & & 0.12 \\
\hline & Hospital admissions & Number of hospital admissions & $L D=26 \% L C=32 \%$ & & & \\
\hline & Miss a medical appointment & $\begin{array}{l}\text { Non-medical attendance ( }<8 \text { office } \\
\text { visits) }\end{array}$ & & $\mathrm{OR}=1.66$ & Cl: $0.86-3.20$ & 0.13 \\
\hline $\begin{array}{l}\text { Linsky et al. (19), } \\
\text { United States }\end{array}$ & Use of colorectal cancer screening & $\begin{array}{l}\text { Self-reported rates of FOBT and } \\
\text { endoscopy }\end{array}$ & $\begin{array}{l}E C=50.8 \% \mathrm{LD}=37.9 \% \\
\mathrm{LC}=28.9 \%\end{array}$ & $\begin{array}{l}\mathrm{LCOR}=0.57 \\
\mathrm{LD} O R=0.84\end{array}$ & Cl: $0.46-0.71$ Cl:0.58-1.2 & \\
\hline \multirow{4}{*}{$\begin{array}{l}\text { Parker et al. (20), } \\
\text { United States }\end{array}$} & Glycated hemoglobin (HbA1c) & Control (HbA1c < 8\%) & $\mathrm{LD}=63 \% \mathrm{LC}=68 \%$ & & & $<0.05$ \\
\hline & Glycated hemoglobin (HbA1c) & Poor control (HbA1c > 9\%) & $\mathrm{LD}=21 \% \mathrm{LC}=18 \%$ & & & \\
\hline & Low-density lipoprotein (LDL) & LDL control (LDL < 100 mg/dL) & $\mathrm{LD}=65 \% \mathrm{LC}=76 \%$ & & & 0.03 \\
\hline & Systolic blood pressure (SBP) & Pressure control (SBP < 140 mmHg) & $\mathrm{LD}=78 \% \mathrm{LC}=84 \%$ & & & \\
\hline \multirow{7}{*}{$\begin{array}{l}\text { Biswas et al. (21), } \\
\text { Australia }\end{array}$} & Door-to-balloon time & Time in minutes & $\mathrm{LD}=71 \mathrm{~min} L C=68 \mathrm{~min}$ & & IQR: 48-112 IQR: 44-103 & 0.21 \\
\hline & Total ischaemic time & $\begin{array}{l}\text { Time in minutes from symptom onset } \\
\text { to first balloon inflation in a coronary } \\
\text { artery }\end{array}$ & $\mathrm{LD}=281 \mathrm{~min} L C=203 \mathrm{~min}$ & & $\begin{array}{l}\text { IQR: 160-720 IQR: } \\
\text { 150-350 }\end{array}$ & 0.01 \\
\hline & Median symptom-to-door time & & & $\mathrm{OR}=1.63$ & Cl: $1.05-2.54$ & 0.03 \\
\hline & Median length of hospital stays & Time in days & $\begin{array}{l}3 \text { days, equal between LD } \\
\text { and LC }\end{array}$ & & & 0.70 \\
\hline & Major adverse cardiac events (MACE) & & $\mathrm{LD}=7.1 \% \mathrm{LC}=5.8 \%$ & & & 0.61 \\
\hline & Mortality & Time in days ( 30 days) & $\mathrm{LD}=9.1 \% \mathrm{LC}=7.8 \%$ & & & 0.69 \\
\hline & Unplanned readmissions & Time in days ( 30 days) & $L D=9.1 \% \mathrm{LC}=9.7 \%$ & & & 0.85 \\
\hline Karra et al. (22), India & $\begin{array}{l}\text { Receipt of post-partum contraception } \\
\text { counseling (PPIUD) }\end{array}$ & $\begin{array}{l}\text { Received at least one advice of family } \\
\text { planning counseling }\end{array}$ & & $\mathrm{OR}=0.548$ & Cl: $0.406,0.738$ & \\
\hline \multirow[t]{3}{*}{$\begin{array}{l}\text { Eamranond et al. (23), } \\
\text { United States }\end{array}$} & Receipt of exercise counseling & $\begin{array}{l}\text { Having documented counseling for } \\
\text { exercise directly related to overall } \\
\text { cardiovascular health }\end{array}$ & $L D=43 \% \mathrm{LC}=62 \%$ & $\mathrm{OR}=2.2$ & $\mathrm{Cl}: 1.4,3.7$ & 0.002 \\
\hline & Receipt of diet and counseling & $\begin{array}{l}\text { Having documented counseling for } \\
\text { diet directly related to overall } \\
\text { cardiovascular health }\end{array}$ & $\mathrm{LD}=44 \% \mathrm{LC}=70 \%$ & $\mathrm{OR}=2.1$ & $\mathrm{Cl}: 1.3,3.5$ & 0.005 \\
\hline & Receipt of smoking counseling & $\begin{array}{l}\text { Having documented counseling for } \\
\text { smoking directly related to overall } \\
\text { cardiovascular health }\end{array}$ & $\mathrm{LD}=57 \% \mathrm{LC}=63 \%$ & $\mathrm{OR}=1.3$ & Cl: $0.8,2.1$ & 0.36 \\
\hline $\begin{array}{l}\text { Eamranond et al. (24), } \\
\text { United States }\end{array}$ & Hyperlipidaemia & Lipid profile within last five years & $\mathrm{LD}=92 \% \mathrm{LC}=95 \%$ & $\mathrm{RR}=1.04$ & Cl: $0.76,1.31$ & \\
\hline
\end{tabular}


TABLE 3 | Continued

\begin{tabular}{|c|c|c|c|c|c|c|}
\hline $\begin{array}{l}\text { Primary author, } \\
\text { publication date, } \\
\text { location }\end{array}$ & Outcomes & Measures & $\begin{array}{l}\text { Language discordance } \\
\text { (LD) vs. language } \\
\text { concordance (LC) }\end{array}$ & $\begin{array}{l}\text { Relative risk } \\
\text { (RR)/odds ratio } \\
\text { (OR)/mean/prevalence }\end{array}$ & $\begin{array}{l}\text { 95\% Confidence intervals } \\
\text { (CI)/interquartile range } \\
\text { (IQR) }\end{array}$ & $P$-value \\
\hline & Diabetes & $\begin{array}{l}\text { Fasting glucose (or a normal random } \\
\text { glucose) within last } 3 \text { years }\end{array}$ & $\mathrm{LD}=92 \% \mathrm{LC}=93 \%$ & $\mathrm{RR}=1.01$ & Cl: $0.76,1.27$ & \\
\hline & Cervical Cancer & Pap smear within last 3 years & $\mathrm{LD}=74 \% \mathrm{LC}=76 \%$ & $\mathrm{RR}=1.02$ & $\mathrm{Cl}=0.72,1.32$ & \\
\hline & Breast Cancer & Mammogram within last 2 years & $\mathrm{LD}=87 \% \mathrm{LC}=89 \%$ & $\mathrm{RR}=1.01$ & $\mathrm{Cl}=0.72,1.30$ & \\
\hline & Colorectal Cancer & $\begin{array}{l}\text { FOBT, sigmoidoscopy, barium } \\
\text { enema, a/o colonoscopy }\end{array}$ & $\mathrm{LD}=72 \% \mathrm{LC}=47 \%$ & $\mathrm{RR}=0.78$ & $\mathrm{Cl}=0.61,0.99$ & \\
\hline $\begin{array}{l}\text { Fernández et al. (25), } \\
\text { United States }\end{array}$ & Glycaemic control & $\begin{array}{l}\text { Poor Glycaemic control (HbA1c > } \\
9 \%)\end{array}$ & $\mathrm{LD}=27.8 \% \mathrm{LC}=16.1 \%$ & $\mathrm{OR}=1.98$ & $\mathrm{Cl}=1.03,3.80$ & 0.04 \\
\hline \multirow[t]{5}{*}{$\begin{array}{l}\text { Inagaki, 2017, } \\
\text { United States }\end{array}$} & \multirow[t]{5}{*}{$\begin{array}{l}\text { Post-operative hospital length of stay } \\
\text { after non-emergent inguinal bypass }\end{array}$} & Mean Hospital days & $\mathrm{LD}=11.2 \mathrm{LC}=9.4$ & $\begin{array}{l}\text { Adjusted } \\
\text { Mean ratio }=1.02\end{array}$ & $\mathrm{Cl}=0.85,1.23$ & 0.133 \\
\hline & & Wound infection & $\mathrm{LD}=31.4 \% \mathrm{LC}=25.7 \%$ & $\mathrm{OR}=1.87$ & $\mathrm{Cl}=0.90,3.88$ & 0.095 \\
\hline & & Adverse graft events & $L D=31.4 \% L C=29.0 \%$ & $\mathrm{OR}=1.23$ & $\mathrm{Cl}=0.62,2.45$ & 0.556 \\
\hline & & Readmission & $L D=25.5 \% L C=20.4 \%$ & $\mathrm{OR}=1.51$ & $\mathrm{Cl}=0.77,2.95$ & 0.478 \\
\hline & & ED return visits & $\mathrm{LD}=23.5 \% \mathrm{LC}=27.1 \%$ & $\mathrm{OR}=1.28$ & $\mathrm{Cl}=0.58,2.832$ & 0.546 \\
\hline \multirow{3}{*}{$\begin{array}{l}\text { John-Baptiste, 2004, } \\
\text { Canada }\end{array}$} & Length of stay (LOS) stroke & Time in days & $\mathrm{LD}=26.1 \mathrm{LC}=14.9$ & $\mathrm{RR}=1.29$ & Cl: $1.18-1.42$ & \\
\hline & Length of stay diabetes & Time in days & $L D=11.6 L C=7.3$ & $\mathrm{RR}=1.28$ & Cl: $1.13-1.45$ & \\
\hline & $\begin{array}{l}\text { In-hospital mortality craniotomy } \\
\text { procedures }\end{array}$ & Mortality rate & $\mathrm{LD}=10.8 \% \mathrm{LC}=4.4 \%$ & $\mathrm{OR}=1.98$ & Cl: $1.34-2.94$ & \\
\hline Leng, 2011, USA & Tuberculosis diagnostic & Received tuberculin testing & $L D=7 \% \mathrm{LC}=10 \%$ & & & 0.40 \\
\hline \multirow[t]{3}{*}{$\begin{array}{l}\text { Rostanki et al. (28), } \\
\text { USA }\end{array}$} & $\begin{array}{l}\text { Time to thrombolysis in Acute } \\
\text { Ischemic Stroke }\end{array}$ & Door to imaging (DIT) time & $L D=25 L C=24$ & Median & & 0.5 \\
\hline & & Imaging to Needle (ITN) time & $L D=30 L C=33$ & Median & & 0.3 \\
\hline & & Door- to-needle (DTN) time & $\mathrm{LD}=55 \mathrm{LC}=58$ & Median & & 0.1 \\
\hline Kim et al. (30), USA & Colorectal cancer screening (CCS) & Fecal occult blood test (FOBT) & $\mathrm{LD}=66.2 \% \mathrm{LC}=49.3 \%$ & & & 0.016 \\
\hline \multirow[t]{4}{*}{ Mehler, 2004, USA } & LDL & $\mathrm{Mg} / \mathrm{dl}$ & $\begin{array}{l}\mathrm{LD}=126(34.6) \mathrm{LC}= \\
102(31.9)\end{array}$ & Mean (SD) & & 0.0002 \\
\hline & $\mathrm{HbA1c}$ & $\%$ & $\begin{array}{l}\mathrm{LD}=8.4(1.5) \mathrm{LC}= \\
8.0(1.6)\end{array}$ & Mean (SD) & & 0.007 \\
\hline & Diastolic BP & $\mathrm{mm} \mathrm{Hg}$ & $\begin{array}{l}\mathrm{LD}=82.7(11.0) \mathrm{LC}= \\
76.3(11.0)\end{array}$ & Mean (SD) & & 0.0002 \\
\hline & Systolic BP & $\mathrm{mm} \mathrm{Hg}$ & $\begin{array}{l}\mathrm{LD}=143.2(22.6) \mathrm{LC}= \\
140.6(20.2)\end{array}$ & Mean (SD) & & 0.3 \\
\hline Goncalves 2013, USA & Adequate care 8 mental health visits & $\%$ & $L D=30.4 \mathrm{LC}=58.5$ & Mean difference (28\%) & & $<0.05$ \\
\hline
\end{tabular}

Physician-patient language discordance and poor health outcomes: A systematic review, Spain-UK, 2020.

LD, Language Discordance; LC, Language Concordance; EC, English Concordance; FOBT, Fecal Occult Blood Test. 
targeting healthcare literacy within this minority group, as opposed to language concordance, may address this disparity and increase intent to access screening (36).

Interestingly, four studies did not include race or ethnicity as variables in their methodology at all, limiting their results. Our review revealed a potential superiority of ethnic concordance over language concordance in its effects on health outcomes in areas such as mental health or postpartum contraceptive counseling (22). Furthermore, previous studies have suggested that doctor-patient race concordance substantially impacts utilization of healthcare services and communication, reinforcing the need for studies to acknowledge race and ethnicity as potential confounding factors (37). A growing body of evidence appears to suggest that clinicianpatient language concordance results in greater developments in patient-centered care, as it minimizes communication errors while concomitantly increasing rapport and cementing trust within the clinician-patient relationship. In turn, clinicianpatient language concordance may serve as a cost-saving intervention by reducing the need for an interpreter and thus appointment waiting times, which are often longer for language-appropriate consultations. More effort and time should be devoted to improving the understanding of diagnoses, treatments, and follow-up among patients who experience language-discordant care. In addition, self-report surveys should be developed that assess the understanding of patients in their care plans, so that health professionals become aware of the degree of understanding of their patients and thus adapt their communication toward them. However, there is insufficient literature to assess the acceptability and success of physicianpatient language concordance consultations without the presence of interpreters.

\section{Future Research}

There is an obvious need for more prospective studies to be conducted to assess the effects of language concordance on health outcomes, with a stronger focus on ensuring accurate measures of language concordance and physician fluency within their methodologies, particularly in studies focusing on non-English

\section{REFERENCES}

1. Migration IOf. Global Migration Trends. International Organization for Migration (2020). Avaliable online at: https://www.iom.int/global-migrationtrends (accessed June 19, 2020).

2. Eurostat. Migration and Migrant Population Statistics-Statistics Explained. Eurostat (2019). Avaliable online at: https://ec.europa.eu/eurostat/statisticsexplained/index.php/Migration_and_migrant_population_statistics (accessed June 19, 2020).

3. Chiarenza A, Dauvrin M, Chiesa V, Baatout S, Verrept H. Supporting access to healthcare for refugees and migrants in European countries under particular migratory pressure. BMC Health Serv Res. (2019) 19:513-27. doi: 10.1186/s12913-019-4353-1

4. M FR. English Language Use and Profienciy of Migrants in the UK-Migration Observatory. Migration Observatory (2019). Avaliable online at: https:// migrationobservatory.ox.ac.uk/resources/briefings/english-language- useand-proficiency-of-migrants-in-the- uk/ (accessed May 9, 2020). language concordance. Furthermore, the majority of current studies assessing LEP patients focus on Spanish language, which is not reflective of all global migrant populations in need of language-concordant care. Although Spanish-speaking migrants form the predominant migrant population in USA, the current migrant crisis has led to many fleeing conflict zones and has resulted in a huge influx of Syrian, Afghani, and Iraqi migrants into the EU, all of whom are understudied and are likely to substantially benefit from language concordant care (2).

\section{Conclusions}

Overall, this systematic review highlights that among other issues concerning the health of minority groups, attention to language concordance issue is vital in ensuring optimal patient-centered care. Healthcare professionals must appreciate the importance of improving healthcare literacy, as well as recognizing the influences of race, ethnicity, and gender upon health outcomes. With regard to policymaking, we conclude that there is a need for a wholistic strategy that targets migrant healthcare needs, with a higher focus on linguistic and cultural competence across global healthcare systems and a move toward diversitycompetent care.

\section{AUTHOR CONTRIBUTIONS}

All authors listed have made a substantial, direct and intellectual contribution to the work, and approved it for publication.

\section{ACKNOWLEDGMENTS}

Professor Khan is a distinguished investigator at the University of Granada funded by the Beatriz Galindo (senior modality) program of the Spanish Ministry of Education.

\section{SUPPLEMENTARY MATERIAL}

The Supplementary Material for this article can be found online at: https://www.frontiersin.org/articles/10.3389/fpubh. 2021.629041/full\#supplementary-material
5. Gandhi TK, Burstin HR, Cook EF, Puopolo AL, Haas JS, Brennan TA, et al. Drug complications in outpatients. J Gen Int Med. (2000) 15:149-54. doi: 10.1046/j.1525-1497.2000.04199.x

6. Jih J, Vittinghoff E, Fernandez A. Patient-physician language concordance and use of preventive care services among limited English proficient Latinos and Asians. Public Health Rep (Washington, DC: 1974). (2015) 130:134-42. doi: 10.1177/003335491513000206

7. Lehane D, Campion P. Interpreters: why should the NHS provide them? Br J Gen Pract. (2018) 68:564-5. doi: 10.3399/bjgp18X699905

8. Jaeger FN, Pellaud N, Laville B, Klauser P. Barriers to and solutions for addressing insufficient professional interpreter use in primary healthcare. BMC Health Serv Res. (2019) 19:753. doi: 10.1186/s12913-019-4628-6

9. Integration EWSo. Migrant Health Across Europe. European Web Site on Integration (2020). Avaliable online at: https://ec.europa.eu/migrantintegration/feature/migrant-health-across-europe (accessed June 20, 2020).

10. Okoroh JS, Uribe EF, Weingart S. Racial and ethnic disparities in patient safety. J Patient Safety. (2017) 13:153-61. doi: 10.1097/PTS.0000000000000133 
11. Hsueh L, Hirsh AT, Maupome G, Stewart JC. Patient-provider language concordance and health outcomes: a systematic review, evidence map, and research agenda. Med Care Res Rev. (2021) 78:3-23. doi: $10.1177 / 1077558719860708$

12. Diamond L, Izquierdo K, Canfield D, Matsoukas K, Gany F. A systematic review of the impact of patient-physician non-english language concordance on quality of care and outcomes. J Gen Int Med. (2019) 34:1591-606. doi: 10.1007/s11606-019-04847-5

13. Moher D, Liberati A, Tetzlaff J, Altman DG. Preferred reporting items for systematic reviews and meta-analyses: the PRISMA statement. BMJ. (2009) 339:b2535. doi: 10.1136/bmj.b2535

14. Shea BJ, Grimshaw JM, Wells GA, Boers M, Andersson N, Hamel C, et al. Development of AMSTAR: a measurement tool to assess the methodological quality of systematic reviews. BMC Med Res Methodol. (2007) 7:10. doi: 10.1186/1471-2288-7-10

15. Stang A. Critical evaluation of the Newcastle-Ottawa scale for the assessment of the quality of nonrandomized studies in meta-analyses. Eur J Epidemiol. (2010) 25:603-5. doi: 10.1007/s10654-010-9491-z

16. Coomarasamy A, Khan KS. What is the evidence that postgraduate teaching in evidence based medicine changes anything? A systematic review. BMJ. (2004) 329:1017. doi: 10.1136/bmj.329.7473.1017

17. Dibben GO, Dalal HM, Taylor RS, Doherty P, Tang LH, Hillsdon M. Cardiac rehabilitation and physical activity: systematic review and meta-analysis. Heart (Br Cardiac Soc). (2018) 104:1394-402. doi: 10.1136/heartjnl-2017-312832

18. Manson A. Language concordance as a determinant of patient compliance and emergency room use in patients with asthma. Med Care. (1988) 26:1119-28. doi: 10.1097/00005650-198812000-00003

19. Linsky A, McIntosh N, Cabral H, Kazis LE. Patient-provider language concordance and colorectal cancer screening. J Gen Intern Med. (2011) 26:142-7. doi: 10.1007/s11606-010-1512-9

20. Parker MM. Association of patient physician language concordance and glycemic control for limited-english proficiency latinos with type 2 diabetes (vol 177, pg 380, 2017). JAMA Int Med. (2017) 177:449. doi: 10.1001/jamainternmed.2017.0118

21. Biswas S, Seman M, Cox N, Neil C, Brennan A, Dinh D, et al. Impact of limited English proficiency on presentation and outcomes of patients undergoing primary percutaneous coronary intervention for ST-elevation myocardial infarction. Int Med J. (2018) 48:457. doi: 10.1111/imj.13751

22. Karra M, Pearson E, Canning D, Shah I, de Silva R, Samarasekera A. Ethnolinguistic Concordance and the Receipt of Postpartum IUD Counseling Services in Sri Lanka. Int Perspect Sex Reprod Health. (2018) 44:133-45. doi: $10.1363 / 44 \mathrm{e} 6918$

23. Eamranond PP, Davis RB, Phillips RS, Wee CC. Patient-physician language concordance and lifestyle counseling among Spanish-speaking patients. $J$ Immigr Minor Health. (2009) 11:494-8. doi: 10.1007/s10903-008-9222-7

24. Eamranond PP, Davis RB, Phillips RS, Wee CC. Patient-physician language concordance and primary care screening among Spanish-speaking patients. Med Care. (2011) 49:668-72. doi: 10.1097/MLR.0b013e318215d803

25. Fernandez A, Schillinger D, Warton EM, Adler N, Moffet HH, Schenker $\mathrm{Y}$, et al. Language barriers, physician-patient language concordance, and glycemic control among insured latinos with diabetes: the diabetes study of Northern California (DISTANCE). J Gen Int Med. (2011) 26:170-6. doi: 10.1007/s11606-010-1507-6
26. Inagaki E, Farber A, Kalish J, Siracuse JJ, Zhu C, Rybin DV, et al. Role of language discordance in complication and readmission rate after infrainguinal bypass. J Vasc Surg. (2017) 66:1473-8. doi: 10.1016/j.jvs.2017. 03.453

27. John-Baptiste A, Naglie G, Tomlinson G, Alibhai SMH, Etchells E, Cheung A, et al. The effect of English language proficiency on length of stay and in-hospital mortality. J Gen Int Med. (2004) 19:221-8. doi: 10.1111/j.1525-1497.2004.21205.x

28. Rostanski SK, Stillman J, Williams O, Marshall RS, Yaghi S, Willey JZ. The influence of language discordance between patient and physician on timeto-thrombolysis in acute ischemic stroke. Neurohospitalist. (2016) 6:107-10. doi: $10.1177 / 1941874416637405$

29. Leng JC, Changrani J, Gany FM. Language discordance and testing for latent tuberculosis infection among recent Asian and Latino immigrants. J Commun Health. (2011) 36:228-30. doi: 10.1007/s10900-010-9301-2

30. Kim K, Quinn M, Lam H. Promoting colorectal cancer screening in foreign-born chinese-american women: does racial/ethnic and language concordance matter? J Racial Ethnic Health Disparities. (2018) 5:1346-53. doi: 10.1007/s40615-018-0484-Z

31. Mehler PS, Lundgren RA, Pines I, Doll K. A community study of language concordance in Russian patients with diabetes. Ethn Dis. (2004) 14:584-8.

32. Gonçalves M, Cook B, Mulvaney-Day N, Alegría M, Kinrys G. Retention in mental health care of Portuguese-speaking patients. Transcult Psychiatry. (2013) 50:92-107. doi: 10.1177/13634615124 74622

33. Biswas S, Seman M, Cox N, Neil C, Brennan A, Dinh D, et al. The impact of doctor-patient language discordance on presentation and outcomes of patients undergoing primary PCI for STEMI. Heart Lung Circ. (2017) 26:S341-2. doi: 10.1016/j.hlc.2017.06.692

34. Amano T, González-Varo JP, Sutherland WJ. Languages are still a major barrier to global science. PLoS Biol. (2016) 14:e2000933. doi: 10.1371/journal.pbio.2000933

35. Bertakis KD. The influence of gender on the doctor-patient interaction. Patient Educ Couns. (2009) 76:356-60. doi: 10.1016/j.pec.2009.07.022

36. Reuland DS, Ko LK, Fernandez A, Braswell LC, Pignone M. Testing a Spanish-language colorectal cancer screening decision aid in Latinos with limited English proficiency: Results from a pre-post trial and four month follow-up survey. BMC Med Inform Decis Mak. (2012) 12:53. doi: 10.1186/1472-6947-12-53

37. Laveist TA, Nuru-Jeter A. Is doctor-patient race concordance associated with greater satisfaction with care? J Health Soc Behav. (2002) 43:296-306. doi: $10.2307 / 3090205$

Conflict of Interest: The authors declare that the research was conducted in the absence of any commercial or financial relationships that could be construed as a potential conflict of interest.

Copyright (c) 2021 Cano-Ibáñez, Zolfaghari, Amezcua-Prieto and Khan. This is an open-access article distributed under the terms of the Creative Commons Attribution License (CC BY). The use, distribution or reproduction in other forums is permitted, provided the original author(s) and the copyright owner(s) are credited and that the original publication in this journal is cited, in accordance with accepted academic practice. No use, distribution or reproduction is permitted which does not comply with these terms. 